\title{
Editorial: Children's Competencies Development in the Home Learning Environment
}

\author{
Frank Niklas $^{1 *}$, Caroline Cohrssen ${ }^{2}$, Simone Lehrl ${ }^{3}$ and Amy R. Napoli ${ }^{4}$ \\ ${ }^{1}$ Department of Psychology, Ludwig-Maximilians-University Munich, Munich, Germany, ${ }^{2}$ Faculty of Education, The University \\ of Hong Kong, Hong Kong, China, ${ }^{3}$ Institute of Psychology, University of Bamberg, Bamberg, Germany, ${ }^{4}$ Department of \\ Child, Youth, and Family Studies, University of Nebraska-Lincoln, Lincoln, NE, United States
}

Keywords: home learning environment, home numeracy environment, home literacy environment, parent-child interaction, children's competencies development

\section{Editorial on the Research Topic}

\section{Children's Competencies Development in the Home Learning Environment}

The home learning environment (HLE) is one of the contexts within which young children develop important competencies (e.g., Niklas and Schneider, 2013; Lehrl et al., 2020b), and which affects their long-term development (e.g., Niklas and Schneider, 2017; Lehrl et al., 2020a). Primary caregivers may support children's learning during everyday routine interactions and by shared reading or playing games. Here, it is helpful to differentiate between the home literacy and numeracy environment and their respective associations with children's literacy and numeracy learning (e.g., Niklas and Schneider, 2013, 2014; Lehrl et al., 2014). Further, formal aspects of the HLE include explicit teaching by the primary caregiver, whereas informal aspects of the HLE consist of various activities that foster children's learning, although learning is not the main focus of the activity (cf. Sénéchal and LeFevre, 2002; Skwarchuk et al., 2014). Family intervention programs not only enhance the quality of the HLE, but also support children's competencies development (e.g., Niklas et al., 2016). Meta-analyses show that children who grow up in a high-quality HLE develop greater competencies and are better prepared for school (Sénéchal and Young, 2008; e.g., Mol et al., 2008). In addition, the availability of digital media in many families worldwide offers new possibilities for interventions (e.g., Niklas et al., 2020). The HLE is closely associated with family background variables such as the socioeconomic status (SES) of a family (i.e., families with a high SES tend to provide higher quality HLEs) and the migration background (e.g., Aikens and Barbarin, 2008; Anders et al., 2012; Niklas et al., 2015). Consequently, the HLE acts as a mediator between more distal family characteristics and child outcomes. Further, research indicates that the HLE may not only predict concurrent children's early literacy and numeracy competencies (e.g., Burghardt et al., 2020, Napoli and Purpura, 2018), but also later achievement in school (e.g., Niklas and Schneider, 2017; Lehrl et al., 2020a) as well as more general cognitive abilities (e.g., Howard et al., 2017; Niklas et al., 2018) and socio-emotional outcomes (e.g., Rose et al., 2018; Wirth et al., 2020). Despite the research on the HLE and the findings in recent years, we still do not know how best to operationalize the HLE, through which specific mechanisms the HLE impacts children's learning, and which facets of the HLE are the most important. For instance, in a recent paper by Hornburg et al. (2021), international experts in the field of the home mathematics environment (HME) discussed next steps in the measurement of this construct and concluded that much more work is needed to define and operationalize the HME, so that it can be supported more successfully in research and practise across countries and contexts. Despite more research having been conducted on the home literacy environment than the HME, this issue also applies to the home literacy environment. We are also still in need of successful family intervention approaches 
that are non-intensive and appeal to all families, independent of their background (e.g., Purpura et al., 2017). Finally, we do not yet know how digital media may be associated with and influence the HLE, or whether there are specific cultural and regional HLE differences.

The present Research Topic entitled "Children's Competencies Development in the Home Learning Environment" thus aims to provide a platform for showcasing the latest research on the HLE and to provide more insight into a construct of important scientific and societal impact. It focuses on empirical research and reviews on children's learning in the context of the HLE. For instance, some of the 23 contributions investigated the different facets of the home literacy and/or numeracy environment (e.g., parental attitudes, parental teaching, frequency, and quality of interactions) and their association with child competencies, whereas others focused on the HLE and children's longer-term development in kindergarten and school, and on intervention effects. Further, some studies compared the HLE across different countries and languages, and some studies focused on digital media usage within the HLE. We ordered the 23 papers according to different criteria and characteristics. Here, we decided to differentiate between articles that focused on both the home literacy and the home numeracy environment (Part 1) and articles that focused on either the home literacy environment (Part 2) or the home numeracy environment (Part 3). Articles in Part 4 compared the HLE across different countries and orthographies and articles in Part 5 analysed digital media within the family context. Within each of these parts, original research articles are presented first and reviews are listed at the end. Finally, within the original research articles in each part, cross-sectional research is presented before manuscripts reporting longitudinal data and manuscripts reporting data on younger children are listed before those reporting data on older children. Table 1 shows an overview of all articles included in this Research Topic and provides information about the article type, the focus variables, the sample (or the studies included in the reviews), the study type (i.e., cross-sectional, longitudinal, or theoretical), and the focus country/ies of the paper. In the following, we briefly highlight key findings from each paper.

Part 1 consists of three studies that consider a more general HLE and thus aspects of both the home numeracy and the home literacy environment. In the paper by Napoli et al. the authors examine characteristics of the child and family that relate to the frequency of parent-child literacy and numeracy engagement. Although some characteristics (i.e., parent education and children's age) were related to both literacy and numeracy engagement, parents' beliefs about the importance of literacy were not related to literacy engagement but beliefs about the importance of numeracy were related to numeracy engagement. The second paper by Susperreguy et al. analysed the association of the HLE with children's numeracy outcomes in a sample of 173 Mexican children, aged 3 to 6 years, living in families with high- vs. low-SES. Whereas, parents with high-SES reported a higher frequency of home literacy activities compared with families with low-SES, no such differences were found for numeracy activities. However, home numeracy activities were significantly associated with numeracy skills of children from families with high-SES only. Consequently, the authors' findings indicate that the socioeconomic status of the family should be considered a moderator of the relations between the home numeracy environment and children's early numeracy skills. The third paper by King et al. investigated how time-specific and construct-specific aspects of the home learning environment are related to children's academic skills, and externalising behaviours, using data from the NICHD Study of Early Child Care and Youth Development $(N=1,364)$. They show that although the overall, stable HLE indicator as measured through the Early Childhood Home Observation for Measurement of the Environment Inventory (EC-HOME) at 36 and 54 months (Caldwell and Bradley, 1984) was positively associated with language skills and negatively associated with externalising behaviours, there is also a construct- and timespecific association between the HLE and children's language and mathematics skills. The specific construct "stimulation" was uniquely associated with children's language and mathematics skills, above and beyond the quality of the overall home learning environment.

Part 2 focuses explicitly on the home literacy environment. Here, Tremblay et al. analysed 45 parent-adolescent dyads with a retrospective and current book title and author recognition tests in their brief research report. They found that early reading experiences of the adolescents in this study related to their later reading preferences, which in turn were associated with the current literacy skills of these adolescents. Their findings indicate a long-lasting impact of early shared reading experiences on subsequent interest in reading, as well as on later literacy outcomes well into adolescence. The second paper of Part 2 by Lau and Richards examined the relation between the home literacy environment and ethnic Chinese children's development of English as a second language. Specifically, the authors considered children's English vocabulary, phonological awareness, letter knowledge, and word reading skills. The results indicate a wide range of home literacy support for English language development, and differences in the relations between the home literacy environment and children's skills. The study adds to the growing body of literature examining children's home literacy environment in a multilingual context. In the third paper, Attig and Weinert used data from the German National Educational Panel Study (NEPS) to explore longitudinal relations between the process (i.e., parental interaction behaviour and joint picture book reading) and structural (i.e., socioeconomic status) characteristics of the home environment and children's language skills. They found that families' socioeconomic status was related to each process characteristic, and that several of these characteristics were related to children's vocabulary and grammar skills. In the fourth paper by Linberg et al. data from the German NEPS was also used to investigate the specific relations between quantitative (e.g., frequency of shared book reading) and qualitative (e.g., sensitivity and stimulation during parentchild interaction) indicators of the HLE at age 2 years, as well as the specific impact of attending low threshold parent-child courses in shaping children's vocabulary development between 2 and 3 years of age. The results indicate that the attending 
TABLE 1 | Overview of the articles included in the Research Topic on home learning environment and child outcomes.

\begin{tabular}{|c|c|c|c|c|c|c|c|}
\hline Parts & References & Article title & Article type & Focus variables & Sample/Included studies & $\begin{array}{l}\text { Study } \\
\text { type }\end{array}$ & Focus countries \\
\hline \multirow[t]{3}{*}{$\begin{array}{l}\text { Part 1: research } \\
\text { on a general HLE }\end{array}$} & Napoli et al. & $\begin{array}{l}\text { Characteristics related to } \\
\text { parent-child literacy and } \\
\text { numeracy practises in } \\
\text { pre-school }\end{array}$ & $\begin{array}{l}\text { Original research } \\
\text { article }\end{array}$ & $\begin{array}{l}\text { Child and family characteristics underlying HLitE } \\
\text { and HNE-parent education, home literacy and } \\
\text { numeracy practises, parents' beliefs of the } \\
\text { importance of literacy and numeracy }\end{array}$ & $\begin{array}{l}199 \text { pre-school children }(M \\
\text { age }=4.16 \text { years })\end{array}$ & C & US \\
\hline & Susperreguy et al. & $\begin{array}{l}\text { Home learning } \\
\text { environments of children in } \\
\text { Mexico in relation to } \\
\text { socioeconomic status }\end{array}$ & $\begin{array}{l}\text { Original research } \\
\text { article }\end{array}$ & $\begin{array}{l}\text { SES, HLE (frequency of parental formal home } \\
\text { numeracy and literacy activities, parental academic } \\
\text { expectations), and children's numeracy performance }\end{array}$ & $\begin{array}{l}173 \text { pre-school children } \\
\text { (aged 3-6 years) M age (low } \\
\text { SES) = } 56.75 \text { months; M } \\
\text { age (high SES) }=55.56 \\
\text { months }\end{array}$ & C & Mexico \\
\hline & King et al. & $\begin{array}{l}\text { Construct-Specific and } \\
\text { timing-specific aspects of } \\
\text { the home environment for } \\
\text { children's school readiness }\end{array}$ & $\begin{array}{l}\text { Original research } \\
\text { article }\end{array}$ & $\begin{array}{l}\text { construct- and timing-specific aspects of HLE } \\
\text { (stimulation and responsivity construct) for } \\
\text { language, maths, and externalising behaviour; } \\
\text { school readiness }\end{array}$ & $\begin{array}{l}1,364 \text { children }(\mathrm{NICHD} \\
\text { data); } \mathrm{M} \text { age }(\mathrm{t} 1)=36 \\
\text { month; } \mathrm{M} \text { age }(\mathrm{t} 2)=54 \\
\text { months }\end{array}$ & L & US \\
\hline \multirow[t]{5}{*}{$\begin{array}{l}\text { Part 2: research on } \\
\text { the home literacy } \\
\text { environment }\end{array}$} & Tremblay et al. & $\begin{array}{l}\text { From storybooks to novels: } \\
\text { a retrospective approach } \\
\text { linking print exposure in } \\
\text { childhood to adolescence }\end{array}$ & $\begin{array}{l}\text { Brief research } \\
\text { report }\end{array}$ & $\begin{array}{l}\text { shared storybook reading in childhood and current } \\
\text { print exposure in adolescence, vocabulary, word } \\
\text { reading, and spelling skills }\end{array}$ & $\begin{array}{l}45 \text { parent-adolescent } \\
\text { dyads; } \mathrm{M} \text { age }(\text { parents })= \\
47.59, \mathrm{M} \text { age (children) }= \\
\text { Grades } 7-11\end{array}$ & C & Canada \\
\hline & Lau and Richards & $\begin{array}{l}\text { Home literacy environment } \\
\text { and children's english } \\
\text { language and literacy skills } \\
\text { in Hong Kong }\end{array}$ & $\begin{array}{l}\text { Original research } \\
\text { article }\end{array}$ & $\begin{array}{l}\text { HLitE, children's language and literacy development } \\
\text { (English skills) }\end{array}$ & $\begin{array}{l}149 \text { children ( } \mathrm{M} \text { age }=59 \\
\text { months) }\end{array}$ & C & Hong Kong \\
\hline & Attig and Weinert & $\begin{array}{l}\text { What impacts early } \\
\text { language skills? Effects of } \\
\text { social disparities and } \\
\text { different process } \\
\text { characteristics of the home } \\
\text { learning environment in the } \\
\text { first } 2 \text { years }\end{array}$ & $\begin{array}{l}\text { Original research } \\
\text { article }\end{array}$ & HLitE, SES, and children's language skills & $\begin{array}{l}\text { 2,272 families with } \\
2 \text {-year-old children ( } M \text { age }= \\
26 \text { months) }\end{array}$ & L & Germany \\
\hline & Linberg et al. & $\begin{array}{l}\text { The early years home } \\
\text { learning } \\
\text { environment-associations } \\
\text { with parent-child-course } \\
\text { attendance and children's } \\
\text { vocabulary at age } 3\end{array}$ & $\begin{array}{l}\text { Original research } \\
\text { article }\end{array}$ & $\begin{array}{l}\text { HLitE, attendance of low threshold } \\
\text { parent-child-courses, vocabulary development, } \\
\text { family background }\end{array}$ & $\begin{array}{l}1,013 \text { children between } 2 \\
\text { and } 3 \text { years (wave } 1: \mathrm{M} \text { age } \\
=6.97 \text { months; wave } 2: \mathrm{M} \\
\text { age }=13.36 \text { months; wave } \\
\text { 3: } \mathrm{M} \text { age }=26.49 \text { months; } \\
\text { wave } 4: \mathrm{M} \text { age }=38.40 \\
\text { months) }\end{array}$ & L & Germany \\
\hline & Niklas et al. & $\begin{array}{l}\text { The home literacy } \\
\text { environment as a mediator } \\
\text { between parental attitudes } \\
\text { towards shared reading and } \\
\text { children's linguistic } \\
\text { competencies }\end{array}$ & $\begin{array}{l}\text { Original research } \\
\text { article }\end{array}$ & HLitE and parental attitudes & $\begin{array}{l}133 \text { children (average age at } \\
\mathrm{t} 1: 3 \text { years) }\end{array}$ & L & Germany \\
\hline
\end{tabular}


TABLE 1 | Continued

\begin{tabular}{|c|c|c|c|c|c|c|c|}
\hline Parts & References & Article title & Article type & Focus variables & Sample/Included studies & $\begin{array}{l}\text { Study } \\
\text { type }\end{array}$ & Focus countries \\
\hline & Ebert et al. & $\begin{array}{l}\text { Differential effects of the } \\
\text { home language and literacy } \\
\text { environment on child } \\
\text { language and theory of } \\
\text { mind and their relation to } \\
\text { socioeconomic background }\end{array}$ & $\begin{array}{l}\text { Original research } \\
\text { article }\end{array}$ & $\begin{array}{l}\text { home language and literacy environment, language } \\
\text { development, TOM, SES }\end{array}$ & $\begin{array}{l}224 \text { pre-school children }(3 ; 6 \\
\text { years) } \mathrm{M} \text { age }(\mathrm{t} 1)=41.87 \\
\text { months }\end{array}$ & L & Germany \\
\hline & Silinskas et al. & $\begin{array}{l}\text { Home literacy activities and } \\
\text { children's reading skills, } \\
\text { independent reading, and } \\
\text { interest in literacy activities } \\
\text { from kindergarten to grade } 2\end{array}$ & $\begin{array}{l}\text { Original research } \\
\text { article }\end{array}$ & $\begin{array}{l}\text { Home Literacy Model and children's engagement in } \\
\text { literacy activities at home and at school (children's } \\
\text { independent reading, children's interest in literacy, } \\
\text { parent teaching) }\end{array}$ & $\begin{array}{l}378 \text { children from } \\
\text { pre-school through grade } 2 \\
\text { ( } \mathrm{M} \text { age }(\mathrm{t} 1)=67.7 \text { months) }\end{array}$ & $\mathrm{L}$ & Finland \\
\hline & Cohen et al. & $\begin{array}{l}\text { Longitudinal effects of the } \\
\text { family support program } \\
\text { Chancenreich on parental } \\
\text { involvement and the } \\
\text { language skills of pre-school } \\
\text { children }\end{array}$ & $\begin{array}{l}\text { Original research } \\
\text { article }\end{array}$ & $\begin{array}{l}\text { (1) Attendance of the Chancenreich program and } \\
\text { attendance of further educational programs; (2) } \\
\text { Family characteristics and attendance rates of } \\
\text { program's course; (3) children's vocabulary and } \\
\text { grammar development }\end{array}$ & $\begin{array}{l}\mathrm{N}(\mathrm{t} 1)=182 ; \mathrm{N}(\mathrm{t} 2)=162 \\
\text { children }(\mathrm{T} 1: \mathrm{M} \text { age }=41 \\
\text { months, } \mathrm{T} 2: \mathrm{M} \text { age }=68 \\
\text { months) }\end{array}$ & L & Germany \\
\hline & Grolig & $\begin{array}{l}\text { Shared storybook reading } \\
\text { and oral language } \\
\text { development: a } \\
\text { bioecological perspective }\end{array}$ & Review & $\begin{array}{l}\text { shared storybook reading and oral language } \\
\text { development; interplay of children's, adults' and } \\
\text { books' characteristics; HLitE, child care learning } \\
\text { environment }\end{array}$ & $\begin{array}{l}\text { Determinants of the shared } \\
\text { reading triad's effects on } \\
\text { language skills: } \\
\text { Bronfenbrenner's } \\
\text { bioecological model (1994); } \\
\text { shared reading in the HLE } \\
\text { (Sénéchal and LeFevre, } \\
\text { 2002) }\end{array}$ & $\mathrm{T}$ & - \\
\hline \multirow[t]{3}{*}{$\begin{array}{l}\text { Part 3: research } \\
\text { on the home } \\
\text { mathematical } \\
\text { environment }\end{array}$} & Purpura et al. & $\begin{array}{l}\text { Examining the factor } \\
\text { structure of the home } \\
\text { mathematics environment to } \\
\text { delineate Its role in } \\
\text { predicting pre-school } \\
\text { numeracy, mathematical } \\
\text { language, and spatial skills }\end{array}$ & $\begin{array}{l}\text { Original research } \\
\text { article }\end{array}$ & $\begin{array}{l}\text { Home mathematical environment (direct numeracy, } \\
\text { indirect numeracy, spatial) and child outcomes } \\
\text { (numeracy, mathematical language, spatial skills) }\end{array}$ & $\begin{array}{l}129 \text { pre-school children } \\
\text { (Mage }=4.71 \text { years })\end{array}$ & C & US \\
\hline & Bachman et al. & $\begin{array}{l}\text { Triangulating multi-method } \\
\text { assessments of parental } \\
\text { support for early math skills }\end{array}$ & $\begin{array}{l}\text { Original research } \\
\text { article }\end{array}$ & $\begin{array}{l}\text { Parental support for early math (math talk, home } \\
\text { math activities; frequency, type, and content of } \\
\text { activities and parental talk) }\end{array}$ & $\begin{array}{l}128 \text { parents }(\mathrm{M} \text { age }= \\
24-56 \text { year old) of } \\
4 \text {-year-old children }\end{array}$ & C & US \\
\hline & De Keyser et al. & $\begin{array}{l}\text { No association between the } \\
\text { home math environment } \\
\text { and numerical and } \\
\text { patterning skills in a large } \\
\text { and diverse sample of } 5 \text { - to } \\
6 \text {-year-olds }\end{array}$ & $\begin{array}{l}\text { Original research } \\
\text { article }\end{array}$ & $\begin{array}{l}\text { HNE (home math activities, parental expectations, } \\
\text { parental attitudes) and children's mathematical skills }\end{array}$ & $\begin{array}{l}353 \text { pre-school children (M } \\
\text { age }=70.03 \text { months) }\end{array}$ & C & Belgium \\
\hline
\end{tabular}


TABLE 1 | Continued

\begin{tabular}{|c|c|c|c|c|c|c|c|}
\hline Parts & References & Article title & Article type & Focus variables & Sample/Included studies & $\begin{array}{l}\text { Study } \\
\text { type }\end{array}$ & Focus countries \\
\hline & Dowker & $\begin{array}{l}\text { Home numeracy and } \\
\text { pre-school children's } \\
\text { mathematical development: } \\
\text { Expanding home numeracy } \\
\text { models to include parental } \\
\text { attitudes and emotions }\end{array}$ & Review & $\begin{array}{l}\text { home numeracy, parental attitudes and beliefs, and } \\
\text { children's mathematical performance, gender } \\
\text { stereotypes, parental mathematics anxiety on } \\
\text { children's anxiety and performance }\end{array}$ & $\begin{array}{l}\text { Home Numeracy Model } \\
\text { (Skwarchuk et al., 2014) }\end{array}$ & $\mathrm{T}$ & $\begin{array}{l}\text { Germany, } \\
\text { Philippines, } \\
\text { Ghana, Chile, Italy }\end{array}$ \\
\hline & Mutaf-Yildiz et al. & $\begin{array}{l}\text { Probing the relationship } \\
\text { between home numeracy } \\
\text { and chldren's mathematical } \\
\text { skills: a systematic review }\end{array}$ & Systematic review & $\begin{array}{l}\text { HNE and children's mathematical skills (formal and } \\
\text { informal skills) }\end{array}$ & $\begin{array}{l}37 \text { articles ( } \mathrm{M} \text { age } 14-70 \\
\text { months approx.) }\end{array}$ & $\mathrm{T}$ & $\begin{array}{l}\text { US, Chile, } \\
\text { Germany, China, } \\
\text { UK, South Africa, } \\
\text { Netherlands, Italy, } \\
\text { Belgium, Russia, } \\
\text { Canada, Greece }\end{array}$ \\
\hline \multirow[t]{3}{*}{$\begin{array}{l}\text { Part 4: research } \\
\text { on the HLE across } \\
\text { countries and } \\
\text { orthograpies }\end{array}$} & Justice et al. & $\begin{array}{l}\text { Parents' growth mindsets } \\
\text { and home-learning } \\
\text { activities: a cross-cultural } \\
\text { comparison of Danish and } \\
\text { US parents }\end{array}$ & $\begin{array}{l}\text { Original research } \\
\text { article }\end{array}$ & $\begin{array}{l}\text { HLE (family learning activities, learning extensions, } \\
\text { parental time investment, parental school } \\
\text { involvement) and parental mindset (ability and effort } \\
\text { mindset) }\end{array}$ & $\begin{array}{l}497 \text { parents with at least } \\
\text { one child aged between } 3 \\
\text { and } 5 \text { years }(N \text { danish = } \\
325 ; N \text { USA }=172)\end{array}$ & $\mathrm{C}$ & Denmark, US \\
\hline & Inoue et al. & $\begin{array}{l}\text { Home literacy environment } \\
\text { and early literacy } \\
\text { development across } \\
\text { languages varying in } \\
\text { orthographic consistency }\end{array}$ & $\begin{array}{l}\text { Original research } \\
\text { article }\end{array}$ & $\begin{array}{l}\text { HLitE, early literacy development, and varying } \\
\text { orthographic constistency (parents'teaching of } \\
\text { reading and spelling) }\end{array}$ & $\begin{array}{l}714 \text { first graders into } \\
\text { second grade (aged } 6+ \\
\text { years) M age different in all } \\
\text { countries/samples }\end{array}$ & L & $\begin{array}{l}\text { Canada, } \\
\text { Netherlands, } \\
\text { Austria, Greece }\end{array}$ \\
\hline & Cheung et al. & $\begin{array}{l}\text { Home literacy and } \\
\text { numeracy environments in } \\
\text { Asia }\end{array}$ & Review & $\begin{array}{l}\text { HLE and parents' interest and abilities in } \\
\text { Asia/learning- related beliefs and attitudes of } \\
\text { parents in Asia, HLitE, and HNE, effectiveness of } \\
\text { programs that aim to improve the home learning } \\
\text { environment }\end{array}$ & $\begin{array}{l}\text { Studies that have been } \\
\text { conducted in different parts } \\
\text { of Asia (China, the } \\
\text { Philippines, India, Iran, } \\
\text { Turkey, and the United Arab } \\
\text { Emirates) }\end{array}$ & $\mathrm{T}$ & $\begin{array}{l}\text { China, Philippines, } \\
\text { India, Iran, Turkey, } \\
\text { United Arab } \\
\text { Emirates }\end{array}$ \\
\hline \multirow[t]{3}{*}{$\begin{array}{l}\text { Part 5: research } \\
\text { on the digital } \mathrm{HLE}\end{array}$} & Lehrl et al. & $\begin{array}{l}\text { The home learning } \\
\text { environment in the digital } \\
\text { age-associations between } \\
\text { self-reported "analogue" } \\
\text { and "digital" home learning } \\
\text { environment and children's } \\
\text { socio-emotional and } \\
\text { academic outcomes }\end{array}$ & $\begin{array}{l}\text { Original research } \\
\text { article }\end{array}$ & $\begin{array}{l}\text { Analogue and digital HLE and children's } \\
\text { social-emotional and academic competencies }\end{array}$ & $\begin{array}{l}4,914 \text { children aged } 0-5 \\
\text { years (Growing up in } \\
\text { Germany II data)/M age } \\
\text { (toddler sample) }=27.4 \\
\text { months; } \mathrm{M} \text { age (pre-school) } \\
=58.3 \text { months }\end{array}$ & $\mathrm{C}$ & Germany \\
\hline & $\begin{array}{l}\text { Segers and } \\
\text { Kleemans }\end{array}$ & $\begin{array}{l}\text { The impact of the digital } \\
\text { home environment on } \\
\text { kindergartners' language } \\
\text { and early literacy }\end{array}$ & $\begin{array}{l}\text { Original research } \\
\text { article }\end{array}$ & $\begin{array}{l}\text { Digital HLitE vs. analogue HLitE, children's language } \\
\text { and literacy levels, parental expectations }\end{array}$ & $\begin{array}{l}70 \text { pre-school children }(M \\
\text { age }=5 \text { years, } 11 \text { months })\end{array}$ & $\mathrm{C}$ & Netherlands \\
\hline & Dore et al. & $\begin{array}{l}\text { Associations between } \\
\text { children's media use and } \\
\text { language and literacy skills }\end{array}$ & $\begin{array}{l}\text { Original research } \\
\text { article }\end{array}$ & Media use, children's language, and literacy skills & $\begin{array}{l}1,583 \text { children from } \\
\text { pre-school through } 3 \text { rd } \\
\text { grade }\end{array}$ & L & US \\
\hline
\end{tabular}

HLE, Home Learning Environment; HLitE, Home Literacy Environment; HNE, Home Numeracy Environment; SES, socioeconomic status; ToM, Theory of Mind; c, cross-sectional study; I, Iongitudinal study; t, theoretical work. 
parent-child courses enriches both aspects of the HLE, which in turn predict children's vocabulary development. The authors conclude that parent-child courses may be an achieveable target for interventions aimed at very young children. In a longitudinal study by Niklas et al., 133 children aged about 3 years at t1 and parents participated. Here, data related to socioeconomic status, home literacy environment, parental attitudes towards shared reading, and children's linguistic competencies were gathered. The results indicate that parental attitudes towards shared reading seemed to be stable across a 1-year period and that the home literacy environment mediated the effect of parental attitudes towards children's linguistic outcomes. As these attitudes vary in the context of different family socioeconomic backgrounds, the authors conclude that they may also be a good target for interventions. The sixth paper of Part 2 by Ebert et al. examined the specific and differential, longitudinal effects of different facets of the HLE and specific parental mental state language input on language and theory of mind (ToM) development between age 4 and 6 years, using data from 224 monolingual German pre-school children. Here, parental mental state language was defined as high-quality verbal interactions with children on decontextualized topics such as mental states of characters in a book. They found that book exposure and quality of verbal interaction during shared reading is related to both later ToM understanding and language skills. However, the effect of book exposure is mediated by earlier language skills at age 4:6 years. Parental mental state language input was not (additionally) associated with ToM or language skills. However, the effects differed for children from varying SES backgrounds: quality of verbal parent-child interaction and parental mental state language seem to be especially important for children from low SES backgrounds with regard to language and ToM development. Thus, supporting the home language and literacy environment from early on might reduce SES differences not only in language but also in social-cognitive development. In the seventh paper by Silinskas et al., the HOME Literacy Model was tested and expanded within a Finnish sample of children $(N=378)$ transitioning from pre- to primary school over a 3-year period. Through cross-lagged panel analyses they found that both aspects of the HLE, the frequency of shared reading and teaching of reading at home predicted the frequency of children's independent reading 1 year later. Furthermore, they identified children's early literacy skills in pre-school to be a significant predictor for independent reading in Grade 1. Another interesting result is that parents adapted their teaching behaviours to their children's early literacy skills, with showing fewer teaching behaviours for children with advanced skills. However, self-reported interest in reading was not associated with HLE or children's early skills. The results add to the Home Literacy Model through investigating the longitudinal patterns of HLE, early literacy skills, and later independent reading and interest. In the intervention study by Cohen et al., the authors examined the effects of the parent support program Chancenreich on parents' participation in additional educational services and children's vocabulary development and grammar. Parents' participation in the program was related to their later participation in educational services, and to children's vocabulary development between the ages of 3 and 5 years. The study offers initial evidence that family support programs may have longitudinal effects on children's language development. Finally, the review by Grolig investigated the relation between shared storybook reading and oral language development in the home literacy environment and the child care literacy environment. A model is proposed to explain the influence of the interplay between child, adult, and book characteristics on shared reading activities. Drawing on socio-constructivist concepts and Bronfenbrenner's (1994) bioecological model, findings are integrated from psychology, education, and linguistics research and indicate that the effect of shared reading is influenced by characteristics of "literacy agents" as well as the relations between these agents. Further, a combination of questionnaires and recognition tests was found to provide a sufficient evaluation of reading practises in the home literacy environment.

Part 3 of the Research Topic includes manuscripts on the home numeracy (or more general mathematics) environment. The first paper by Purpura et al. examined the factor structure of the HME (general HME factor, direct numeracy, indirect numeracy, and spatial) and tested the association of these factors with children's numeracy, mathematical language, and spatial skills of 129 pre-schoolers from the US. Confirmatory factor analyses indicated that a bifactor model fitted the data best (spatial and a general numeracy factor). In structural equation modelling analyses, only the numeracy factor was able to predict child outcomes when controlling for child and family characteristics. The results highlight the importance of parentchild engagement in specific aspects of mathematics-related activities. In the second article by Bachman et al., the authors used a multimethod approach and assessed mathematics talk during semi-structured observations of parent-child interactions, parent reports on a home math activities questionnaire, and time diaries with a sample of 128 4-year-old children from the US. The findings reveal substantial within-measure variability across all three data sources and some convergence across measures. The authors conclude that this multi-method approach holds great promise for furthering our understanding of when and how parents support early mathematics skills with their preschool-aged children. The third paper by De Keyser et al. reports that no association was found between the home mathematics environment, and numerical and patterning skills in a diverse sample of 353 children aged 5 to 6 years in Belgium. Neither gender nor family socio-economic moderated the association between the home mathematics environment and children's mathematics skills. Small mathematics-related differences were observed in parental expectations and attitudes. One explanation proposed for these findings is that the preschool learning environment may play a role due to high participation rates in high quality pre-schools that are fully government subsidised and which include a focus on children's mathematical learning. The fourth paper is a review by Dowker considering the relation between parents' mathematics anxiety and the home numeracy environment of pre-schoolaged children. Dowker argues for the importance of a broader definition of the home mathematics environment that includes parent mathematics attitudes in addition to activities. The 
author also highlights several areas for future research, including broader aspects of mathematics than just numeracy (e.g., measurement) and different aspects of parents' mathematics anxiety. Finally, the review by Mutaf-Yildiz et al. analysed the association of parent-child interactions with numerical content with children's performance in mathematical tasks. Thirty-seven articles were included in their systematic review and the authors found a positive association between home numeracy and children's mathematical skills. Here, more advanced, compared with basic, numeracy interactions were associated with child competencies and most studies used questionnaires, surveyed mothers, analysed a comprehensive total score of mathematical competencies, and focused on formal home numeracy activities. Contradictory results regarding the relation between home numeracy and mathematical skills across studies may be due to differences in these study characteristics.

Part 4 includes articles that compare the HLE across different countries and orthographies. Here, the first paper by Justice et al. analysed parental mindsets (i.e., parental beliefs about the role of ability and effort in learning) and their association with home learning activities across a Danish sample $(N=325)$ and a sample from the US $(N=172)$. The parents of 3- to 5-yearold children in both countries held similar ability and effort mindsets. However, US parents provided more family learning activities, learning extensions, and parental time investment, whereas the Danish parents reported higher levels of school investments. Further, in the US but not in Denmark, higher levels of effort mindset were associated with higher levels of parental time investment. In the second paper by Inoue et al., the authors examined the association between home literacy environment (HLE) and early literacy development in a sample of, on average, 76- to 79-month-old children learning four alphabetic orthographies varying in orthographic consistency (English: $N=172$; Dutch: $N=120$; German: $N=184$; Greek: $N=238$ ). The children were tested four times: at the beginning and the end of Grade 1 and Grade 2. In addition, parents reported on parent teaching (PT), shared book reading (SBR), and access to literacy resources (ALR) at the beginning of Grade 1. The findings indicated that SBR did not predict any cognitive or early literacy skills in any language, whereas PT was associated with letter knowledge or phonological awareness in Dutch and Greek only, and ALR was associated with emergent literacy skills in all languages. No specific trend in the role of orthographic consistency in the aforementioned relations emerged. Finally, the review by Cheung et al. synthesises research studies on the home literacy and numeracy environments that have been conducted in different parts of Asia, such as China, the Philippines, India, Iran, Turkey, and the United Arab Emirates. They explore how parents in this part of the world perceive their roles in supporting children's early literacy and numeracy development, through which activities they engage their young children in literacy and numeracy, and how effective intervention programs are that aim to improve the HLEs in Asia. Consistent with the findings from major western studies, the authors report that the home learning environment tends to play a critical role in children's early development also in Asia. However, the authors highlight some findings that seem to be specific to the Asian context: some parents, especially those in East Asia, tend to place greater emphasis on academic achievement and regard it as their own responsibility to support their children's learning at home. In comparison, play is not always favoured as a form of learning, although this view seems to be slightly changing. Furthermore, the role of non-parental household members in fostering children's development is specific to Asian homes, which sometimes might even involve non-family members such as domestic helpers. Furthermore, another challenge might be that in many contexts, children in Asia have to be proficient in languages they do not necessarily speak at home in order to attain educational success-a circumstance which can be observed in many western countries too. Overall the review provides a deep insight in the HLEs in Asian families.

In Part 5, three papers are listed that analyse media usage in the family context and thus a digital HLE. The first paper by Lehrl et al. explores the differentiation of an analogue and a digital HLE and their associations with children's parentrated academic and socio-emotional outcomes within two age groups in Germany (toddlers and pre-schoolers; total $N=4,914$ ). They found that analogue and digital HLE activities are two separate constructs of the HLE which are associated, but not interchangeable. Both dimensions explain individual differences in young children's socio-emotional, practical life, and academic skills; however, these associations are age-specific. For toddlers, only analogue HLE activities were associated with better socioemotional and practical life skills. For pre-schoolers, digital HLE activities were associated with weaker socio-emotional skills but higher academic skills. However, analogue HLE showed higher effect sizes for the academic outcomes in this age group. The authors conclude that more research is needed on the supporting and detrimental features of the digital HLE. In the second paper by Segers and Kleemans, the authors also tried to differentiate between a digital and an analogue HLE in a sample of 71 families from the Netherlands. Here, the main caregivers of 71 kindergarteners (mean age about 6 years) filled out a questionnaire on the home environment (expectations, activities, and materials), and the children were assessed on language (vocabulary and grammar) and literacy (beginning phoneme awareness, segmentation skill, and grapheme knowledge) skills. Whereas the authors were able to differentiate both forms of the HLE, only the analogue environment was related to children's language abilities (i.e., parental expectations were associated with both language and literacy abilities). Finally, in a longitudinal study by Dore et al., a larger sample from the USA $[N=$ 1,583 children (PreK $N=238$, kindergarten $N=466$, Grade $1 N=307$, Grade $2 N=326$, and Grade $3 N=246$ )] was analysed concerning their media usage and language and literacy skills both at the beginning of the school year and across the school year. The analyses showed that more than $4 \mathrm{~h}$ of media usage a day predicted lower literacy gains, but not language gains. However, these effects did not hold in multilevel models. Similarly, no negative associations were found in the singletime models, when controlling for various variables. Further, the findings indicated that younger children are not more vulnerable to detrimental effects. The authors point out that given the concern and popular press coverage around children's media 
use, it is important to acknowledge non-significant effects in this domain. Their non-significant associations suggest that societal fears around children's media use may be exaggerated. However, characteristics of children's media use, like educational content or adult co-use, may moderate any potential effects.

To sum up, the collection of papers in this Research Topic provides important findings on the complex nature of the HLE and its association with various child outcomes. It assembles 19 empirical articles sampled from 11 nations, namely Austria, Belgium, Canada, Denmark, Finland, Germany, Greece, Hong Kong, Mexico, the Netherlands, and the USA. Further, four reviews are included that either looked at theoretical constructs in the context of the HLE (two reviews) or analysed its association with child outcomes (one review) and across different countries (one review). In these reviews, studies from 18 nations-namely Belgium, Canada, Chile, China, Germany, Ghana, Greece, India, Iran, Italy, the Netherlands, Philippines, Russia, South Africa, Turkey, United Arab Emirates, the UK, and the USwere discussed. Consequently, this Research Topic represents an international and intercultural mix of data sources and perspectives on the HLE.

\section{REFERENCES}

Aikens, N. L., and Barbarin, O. (2008). Socioeconomic differences in reading trajectories: the contribution of family, neighborhood, and school contexts. J. Educ. Psychol. 100, 235-251. doi: 10.1037/0022-0663.100. 2.235

Anders, Y., Roßbach, H.-G., Weinert, S., Ebert, S., Kuger, S., Lehrl, S., et al. (2012). Home and preschool learning environments and their relations to the development of early numeracy skills. Early Childh. Res. Q. 27, 231-244. doi: 10.1016/j.ecresq.2011.08.003

Bronfenbrenner, U. (1994). "Ecological models of human development" in International Encyclopedia of Education, 2nd Edn, Vol. 3. eds T. Husen and T. N. Postlewaite (Oxford: Pergamon and Elsevier), 1643-1647.

Burghardt, L., Linberg, A., Lehrl, S., and Konrad-Ristau, K. (2020). The relevance of the early years home and institutional learning environments for early mathematical competencies. J. Educ. Res. Online 12, 103-125. Available online at: https://www.pedocs.de/frontdoor.php?source_opus $=21188$

Caldwell, B. M., and Bradley, R. H. (1984). Home Observation for Measurement of the Environment. Little Rock, AR: University of Arkansas at Little Rock.

Hornburg, C. B., Borriello, G. A., Kung, M., Lin, J., Litkowski, E., Cosso, J., et al. (2021). Next directions in measurement of the home mathematics environment: an international and interdisciplinary perspective. J. Num. Cogn. Available online at: https://hira.hope.ac.uk/id/eprint/3296/

Howard, S. J., Powell, T., Vasseleu, E., Johnstone, S., and Melhuish, E. (2017). Enhancing preschoolers' executive functions through embedding cognitive activities in shared book reading. Educ. Psychol. Rev. 29, 153-174. doi: 10.1007/s10648-016-9364-4

Lehrl, S., Ebert, S., Blaurock, S., Roßbach, H.-G., and Weinert, S. (2020a). Long-term and domain-specific relations between the early years home learning environment and students' academic outcomes in secondary school. Sch. Effect. Sch. Improve. 31, 102-124. doi: 10.1080/09243453.2019. 1618346

Lehrl, S., Evangelou, M., and Sammons, P. (2020b). The home learning environment and its role in shaping children's educational development. Sch. Effect. Sch. Improve. 31, 1-6. doi: 10.1080/09243453.2020. 1693487

Lehrl, S., Smidt, W., Große, C., and Richter, D. (2014). Patterns of literacy and numeracy activities in preschool and their relation to structural
The articles cover various samples ranging from 45 to almost 5,000 participants (mostly medium-sized samples from $N=100$ to 500) from early infancy to adolescence (although most focus on pre-school age and kindergarten children). Moreover, this collection grounds a wide range of theoretical approaches, conceptual frameworks, and assessment methods. This leads to highly diverse and nuanced findings concerning the HLE and its association with various child competencies. We hope that the contributions from this Research Topic will spark further scientific work on the HLE and inspire and serve policymakers and practitioners, and that it may lead to new developments concerning the definition, operationalisation, and assessment of the HLE as well as act as a basis for the development of meaningful family interventions.

\section{AUTHOR CONTRIBUTIONS}

All authors listed have made a substantial, direct and intellectual contribution to the work, and approved it for publication. characteristics and children's home activities. Res. Pap. Educ. 29, 577-597. doi: 10.1080/02671522.2013.792865

Mol, S. E., Bus, A. G., de Jong, M. T., and Smeets, D. J. H. (2008). Added value of dialogic parent-child book readings: a meta-analysis. Early Educ. Dev. 19, 7-26. doi: 10.1080/10409280701838603

Napoli, A. R., and Purpura, D. J. (2018). The home literacy and numeracy environment in preschool: cross-domain relations of parent-child practices and child outcomes. J. Exp. Child Psychol. 166, 581-603. doi: 10.1016/j.jecp.2017.10.002

Niklas, F., Annac, E., and Wirth, A. (2020). App-based learning for kindergarten children at home (Learning4Kids): study protocol for cohort 1 and the kindergarten assessments. BMC Pediatrics 20:554. doi: $10.1186 / s 12887-020-02432-y$

Niklas, F., Cohrssen, C., and Tayler, C. (2016). Improving preschoolers' numerical abilities by enhancing the home numeracy environment. Early Educ. Dev. 27, 372-383. doi: 10.1080/10409289.2015.1076676

Niklas, F., Cohrssen, C., and Tayler, C. (2018). Making a difference to children's reasoning skills before school-entry: The contribution of the home learning environment. Contemp. Educ. Psychol. 54, 79-88. doi: $10.1016 /$ j.cedpsych.2018.06.001

Niklas, F., and Schneider, W. (2013). Home literacy environment and the beginning of reading and spelling. Contemp. Educ. Psychol. 38, 40-50. doi: $10.1016 /$ j.cedpsych.2012.10.001

Niklas, F., and Schneider, W. (2014). Casting the die before the die is cast: the importance of the home numeracy environment for preschool children. Euro. J. Psychol. Educ. 29, 327-345. doi: 10.1007/s10212-013-0201-6

Niklas, F., and Schneider, W. (2017). Home learning environment and development of child competencies from kindergarten until the end of elementary school. Contemp. Educ. Psychol. 49, 263-274. doi: 10.1016/j.cedpsych.2017.03.006

Niklas, F., Tayler, C., and Schneider, W. (2015). Home-based literacy activities and children's cognitive outcomes: a comparison between Australia and Germany. Int. J. Educ. Res. 71, 75-85. doi: 10.1016/j.ijer.2015.04.001

Purpura, D. J., Napoli, A. R., Wehrspann, E. A., and Gold, Z. S. (2017). Causal connections between mathematical language and mathematical knowledge: a dialogic reading intervention. J. Res. Educ. Effect. 10, 116-137 doi: 10.1080/19345747.2016.1204639

Rose, E., Lehrl, S., Ebert, S., and Weinert, S. (2018). Long-term relations between children's language, the home literacy environment, and socioemotional 
development from ages 3 to 8. Early Education and Development, 29, 342-356. doi: 10.1080/10409289.2017.1409096

Sénéchal, M., and LeFevre, J.-A. (2002). Parental involvement in the development of children's reading skill: a five-year longitudinal study. Child Dev. 73, 445-460. doi: 10.1111/1467-8624.00417

Sénéchal, M., and Young, L. (2008). The effect of family literacy interventions on children's acquisition of reading from kindergarten to grade 3: a meta-analytic review. Rev. Educ. Res. 78, 880-907. doi: 10.3102/0034654308320319

Skwarchuk, S. L., Sowinski, C., and LeFevre, J. A. (2014). Formal and informal home learning activities in relation to children's early numeracy and literacy skills: the development of a home numeracy model. J Exp Child Psychol. 121, 63-84. doi: 10.1016/j.jecp.2013.11.006

Wirth, A., Ehmig, S. C., Drescher, N., Guffler, S., and Niklas, F. (2020). Facets of the early home literacy environment and children's linguistic and socioemotional competencies. Early Educ. Dev. 31, 892-909. doi: $10.1080 / 10409289.2019 .1706826$

Conflict of Interest: The authors declare that the research was conducted in the absence of any commercial or financial relationships that could be construed as a potential conflict of interest.

Copyright (C) 2021 Niklas, Cohrssen, Lehrl and Napoli. This is an open-access article distributed under the terms of the Creative Commons Attribution License (CC BY).

The use, distribution or reproduction in other forums is permitted, provided the original author(s) and the copyright owner(s) are credited and that the original publication in this journal is cited, in accordance with accepted academic practice. No use, distribution or reproduction is permitted which does not comply with these terms. 